\title{
DECONTAMINATION OF a DIVING SUIT
}

\section{Zbigniew Dabrowiecki, Małgorzata Dąbrowiecka, Romuald Olszański, Piotr Siermontowski}

Maritime \& Hyperbaric Medicine Department, Military Institute of Medicine

\begin{abstract}
When working in chemical or biological environments, contamination is an extremely dangerous issue for the rescue services of the fire department, police and the army.

Modern protective overalls worn by fire fighters or dry "Viking" diving suits made from neoprene or nylon covered with polyurethane have been proven to ensure sufficient protection. However, once the contaminated area is left, there is a need to perform decontamination of the external and internal surfaces of the protective overalls; in order to ensure the clothing continues to offer a high level of comfort and to retain the durability of said protective clothing, it is of course also necessary to perform a drying procedure.

Moreover, there is a risk of a transfer of pathogenic micro-organisms between persons utilising the same protective clothes, particularly in the case of expensive specialist suits. Micro-organisms which may potentially spread through clothing include intestinal bacteria, such as: Salmonella, Shigella, Campylobacter, E. coli (including E. coli O157), C. difficile, viruses inducing infections of the upper respiratory tract and alimentary tract (noraviruses, rotaviruses, adeno and astroviruses). The risk of infection also involves the presence of the flu viruses, herpesviruses and pathogens transferred through skin, such as S. aureus (including MRSA), yeast-like fungi (Candida albicans), fungal strains inducing Tinea pedis and Tinea corporis [1]. Pathogenic micro-organisms can easily transfer from fabric surface onto the body of a person wearing protective clothing.

From the numerous available techniques of decontamination of surfaces, equipment and protective clothing we propose to use for this purpose gaseous hydrogen peroxide $\left(\mathrm{H}_{2} \mathrm{O}_{2}\right)$, a very effective biocidal agent. In field conditions, typical for the activities of rescue crews of the fire department, police and army we assume utilisation of a portable decontamination chamber enabling performance of a complete decontamination process.

The process lasting approximately 3 hours encompasses 3 phases:

- $\quad$ Drying phase;

- Decontamination with gaseous hydrogen peroxide;

- $\quad$ Catalytic combustion phase of hydrogen peroxide residues to a level safe for the environment

The integrated humidity and $\mathrm{H}_{2} \mathrm{O}_{2}$ level sensors ensure automatic control of the entire process and the unique distribution system of gaseous $\mathrm{H}_{2} \mathrm{O}_{2}$ secures full accessibility of the biocidal agent to the external surface of protective clothing as well as its interior. Moreover, the container allows for the conduction of the complete decontamination of the rescue equipment, night vision devices, binoculars, field telephones, radio stations, etc. Upon decontamination cycle completion, we obtain a completely dried suit which can be safely used by another crew member.

Key words: diving, diving suit, decontamination.
\end{abstract}

\section{ARTICLE INFO}

PolHypRes 2016 Vol. 57 Issue 4 pp. 45 - 54

ISSN: 1734-7009 elSSN: 2084-0535

DOI: $10.1515 /$ phr-2016-0025

Pages: 11, figures: 3 , tables: 2

page www of the periodical: www.phr.net.pl

\section{Publisher}

Polish Hyperbaric Medicine and Technology Society
Original article

Submission date: $22.11 .2016 \mathrm{r}$. Acceptance for print: 17.12.2016r. 


\section{INTRODUCTION}

Working in chemical or biological environment contamination is extremely dangerous for the rescue services of the fire department, police and the army. Modern protective overalls worn by fire fighters or dry "Viking" diving suits made from neoprene or nylon covered with polyurethane, have been proven to ensure sufficient protection. However, once the contaminated area is left, there is a need to perform decontamination of the external and internal surface of protective overalls; in order to ensure the clothing continues to offer a high level of comfort and to retain the durability of said protective clothing, it is of course also necessary to perform a drying procedure.

Additionally, there is a risk of a transfer of pathogenic micro-organisms between people using the same clothing, particularly in the case of expensive specialist overalls. Micro-organisms which may potentially spread through clothing include intestinal bacteria, such as: Salmonella, Shigella, Campylobacter, E. coli (including E. coli 0157), C. difficile, viruses inducing infections of the upper respiratory tract and alimentary tract (noraviruses, rotaviruses, adeno and astroviruses). The risk of infection is moreover connected with the flu viruses, herpesviruses and pathogens transferred through skin, such as S. aureus (including MRSA), yeast-like fungi (Candida albicans), fungal strains inducing Tinea pedis and Tinea corporis [1].

It is estimated that a human can daily emit into the environment approximately one million dead skin cells which may contain fungi and bacteria, including $S$. aureus [2].

The survival rate of micro-organisms on various surfaces depends on fabric type, humidity and temperature as well as initial pathogen concentration. Neeley and Maley have studied the survival rate of 22 Gram-positive bacteria species on such materials as: $100 \%$ cotton, $60 \%$ cotton $+40 \%$ polyester, $100 \%$ polyester. All micro-organisms survived at least 1 day, whilst some even up to 90 days on selected materials. Generally, the survival rate of bacteria, viruses and fungi on hydrophobic smooth surfaces is at least 2-4 times higher as compared with such materials as pure cotton (smooth, terry fabrics) or cotton/polyester mixtures $[3,4,5]$.

Pathogenic micro-organisms can easily transfer from a fabric surface onto the body of a person wearing protective clothing. In the work by Sattar et al. it has been indicated that one of the most crucial factors determining the speed of transfer of a pathogen from fabric surface onto a person's hands consists in fabric humidity. Drying of a surface may reduce the transfer of a micro-organism up to 10 times in relation to the transfer from a humid surface onto a humid skin [6].

From the numerous available techniques of decontamination of surfaces, equipment and protective clothing we decided to use for this purpose gaseous hydrogen peroxide $\left(\mathrm{H}_{2} \mathrm{O}_{2}\right)$, a very effective biocidal agent applied, for instance, in the eradication of such dangerous pathogens as Mycobacterium tuberculosis or Clostridium difficile $[7,8]$. a) Working conditions of an air and surface disinfection system

- Room: area $9 \mathrm{~m}^{2}$, height $3.55 \mathrm{~m}$, cubature $32 \mathrm{~m}^{3}$.

- Distance between NOCOSPRAY device and control points: between $80 \mathrm{~cm}$ and $350 \mathrm{~cm}$.

- Device emitting $\mathrm{H}_{2} \mathrm{O}_{2}$ /water/air aerosol: Nocospray manufactured by Oxypharm.

- Aerosol emission speed: $80 \mathrm{~m} / \mathrm{s}$.

- Drop size: 5 microns.

- Decontamination liquid consumption: $1000 \mathrm{ml} /$ hour; $16.6 \mathrm{ml} / \mathrm{min}$.

- Decontaminating agent:

- Nocolyse, stabilised solution $6 \% \mathrm{H}_{2} \mathrm{O}_{2}$, neutral odour;

- Nocolyse, stabilised solution $6 \% \mathrm{H}_{2} \mathrm{O}_{2}$, mint odour;

- Nocolyse One Shot, stabilised solution $12 \%$ $\mathrm{H}_{2} \mathrm{O}_{2}$, neutral odour;

b) Experimental model

A diving suit was placed on a rack in the decontamination room (fig. 1) along with other suit components (fabric samples, metal and rubber parts) to perform material compatibility tests - resistance to a high and long-lasting $\mathrm{H}_{2} \mathrm{O}_{2}$ concentration in the air (fig. 2).

\section{EXPERIMENTAL MODEL}


Fig. 1. A rack with the diving suit.
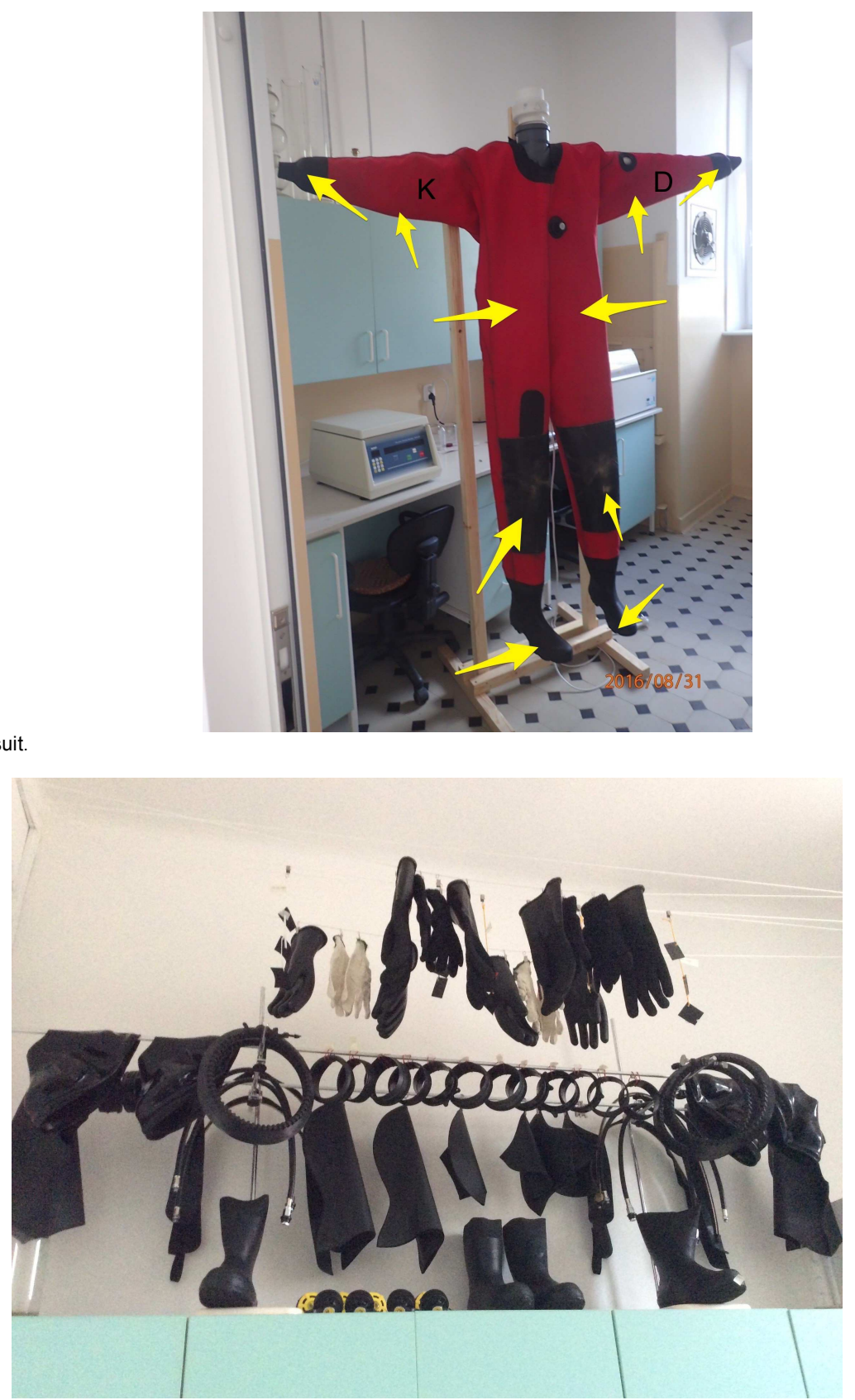

Fig. 2. Particular diving suit components subjected to decontamination.

Spatial concentration of gaseous $\mathrm{H}_{2} \mathrm{O}_{2}$ was monitored with the use of Nocotest strips.

The colour change from green to brown enables determination of the concentration of gaseous hydrogen peroxide in the decontamination room (green: 0.5-1.00 ppm $\mathrm{H}_{2} \mathrm{O}_{2}$, dark brown above $50 \mathrm{ppm}$ ). 


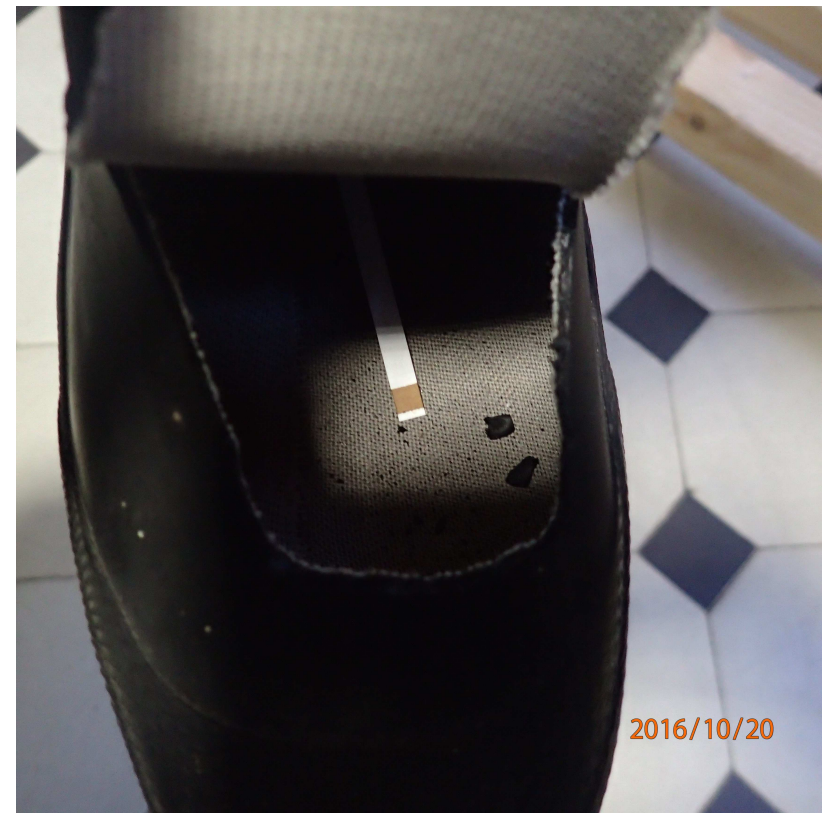

Fig. 3. The placement of $\mathrm{H}_{2} \mathrm{O}_{2}$ concentration test strips.

a) Micro-organism tests

In order to determine the biocidal efficiency of gaseous $\mathrm{H}_{2} \mathrm{O}_{2}$ in relation to bacteria, fungi and yeasts, the tests were conducted with the use of micro-organisms specified in table 1.10 points were assigned on the external surface of the diving suit (see arrows in fig.1), and an additional 8 points in the internal part for the placement of $100 \mu \mathrm{l}$ of an overnight micro-organism culture solution to perform experimental decontamination. 30 minutes from sample inoculation on the right part of the suit (marked with letter $\mathrm{K}$ in fig. 1) the contamination level was tested with the use of the Orion imprint test. Moreover, the level of inactivation of the spores of the Geobacillus stearothermophilus bacteria species was determined by use of a vial biological indicator for hydrogen peroxide sterilisation testing, Bionova $\mathrm{H}_{2} \mathrm{O}_{2}$ (BT91) manufactured by Terragene.

\begin{tabular}{ll}
\hline Bacteria & \\
\hline Acinetobacter baumannii & ATCC 17978 \\
\hline Escherichia coli & ATCC 8739 \\
\hline Legionella pneumophila & ATCC 33152 \\
\hline Legionella longbeachae & ATCC 33462 \\
\hline Pseudomonas aeruginosa & ATCC 9027 \\
\hline Staphylococcus aureus, & ATCC 6538 \\
\hline Spore-forming bacteria & \\
\hline Geobacillus stearothermophilus & ATCC 7953 \\
\hline Bacillus subtilis, & ATCC 6333 \\
\hline Fungi, yeasts & \\
\hline Aspergillus brasiliensis & ATCC 16404 \\
\hline Candida albicans & ATCC 10231
\end{tabular}

Hygicult imprint tests are designed for a fast monitoring of microbiological hygiene and/or initial micro-organism identification (total count of bacteria, yeasts, mould and intestinal bacilli) on various surfaces. The test may be conducted on-site or with the use of a substrate as a convenient transport medium for samples.

The Hygicult TPC test is covered on both sides with Total Plate Count agar, which enables a fast growth of the majority of common micro-organisms. The test is dedicated for the detection of an elevated total count of micro-organisms. The second Hygicult TPC test is covered on both sides with Malt agar, which enables a fast growth of yeast and mould. Bacteria growth is inhibited. The test is dedicated for the detection of an elevated total count of fungi on surfaces.

Hygicult tests provide initial information on microbiological purity as well as the type of a microorganism which causes contamination (depending on the selected Hygicult test). The samples were incubated at the temperature of $35-37^{\circ} \mathrm{C}$ for 24 hours. The contamination level was determined according to the provided model in $\mathrm{jtk} / \mathrm{cm}^{2}$. Biological indicators Bionova $\mathrm{H}_{2} \mathrm{O}_{2}$ (BT91) enable monitoring of hydrogen peroxide decontamination 
processes. Each indicator consists of a plastic vial with a glass ampoule with a culture medium placed inside.

Geobacillus stearothermophilus bacteria spores were provided at the bottom of the plastic vial in the quantity of $2.3 \times 10^{5}$ spores in a single test. Moreover, the test includes a decontamination process indicator provided on the label of each vial, which changes its colour during sterilisation from violet to green.

Before the incubation, the ampoule is to be crushed and the culture medium is to be spread over the bottom of the vial. The micro-organism growth is observable with a change in the culture medium colour from violet to yellow. The final result is obtained after the lapse of 24 hours of incubation at the temperature of $60^{\circ} \mathrm{C}$.

d) Decontamination procedure

The instruction attached to the Nocospray device provides for the use of $1 \mathrm{ml}$ of $6 \%$ hydrogen peroxide solution (Nocolyse, stabilised solution $6 \% \mathrm{H}_{2} \mathrm{O}_{2}$, neutral odour) on an area of $1 \mathrm{~m}^{3}$ of the room subject to decontamination.

With the cubature of $31 \mathrm{~m}^{3}$ it was assumed that following approximately 2 minutes of emission, a 30 minute period of hydrogen peroxide activity should be ensured on all surfaces in the room, with particular attention paid to the diving suit. Hydrogen peroxide penetration of internal surfaces of the suit was secured with an air circulation system operated by a fan. This was followed by a 30 -minute ventilation of the entire room through an active fume hood system. Entry into the room was permitted upon $\mathrm{H}_{2} \mathrm{O}_{2}$ concentration reduction in the air to the level below $1 \mathrm{ppm}$.

During the decontamination with the use of a $12 \%$ hydrogen peroxide solution (Nocolyse One Shot, stabilised solution $12 \% \mathrm{H}_{2} \mathrm{O}_{2}$, neutral odour) the reduction of $\mathrm{H}_{2} \mathrm{O}_{2}$ concentration level to $1 \mathrm{ppm}$ lasted 60 minutes.

The maximum hydrogen peroxide emission time in the performed experiments was 12 minutes, which corresponded to the use of $200 \mathrm{ml}$ of $6 \%$ or $12 \% \mathrm{H}_{2} \mathrm{O}$ solution respectively.

\section{RESULTS}

The decontamination of the tested room with Nocolyse $6 \% \mathrm{H}_{2} \mathrm{O}_{2}$, solution with a 2-minute emission time and a 30-minute total decontamination time guaranteed hydrogen peroxide accessibility to all measurement points in the room. Unfortunately, the distribution of hydrogen peroxide concentrations varied. Also, the level of reduction of the presence of microorganisms on the tested surfaces indicated partial ineffectiveness of the decontamination process, especially with regard to spore-forming bacteria. The application of Nycolyse $6 \% \mathrm{H}_{2} \mathrm{O}_{2}$ was efficient only with a 12-minute emission period and total decontamination time of 6 hours.

The change in the concentration of emitted hydrogen peroxide from $6 \%$ to $12 \%$, i.e. the application of a Nocolyse One Shot preparation, resulted in a radical shortening of the effective decontamination time and allowed the obtainment of a $100 \%$ biocidal efficacy.

The experiment encompassed 5 decontamination procedures with the use of Nocolyse $6 \%$ and various emission times and an effective decontamination time lasting between 30 minutes and 24 hours. The decontamination with the use of Nocolyse One Shot encompassed 6 exposures with the emission time between 2 to 20 minutes and effective decontamination time ranging between 120 to 360 minutes. Upon completion of each decontamination procedure, the room was ventilated in order to remove trace levels of hydrogen peroxide (to a safe level below $1 \mathrm{ppm}$ ).

In order to determine material compatibility, i.e. the resilience of construction elements of the diving suit to a high and long-lasting $\mathrm{H}_{2} \mathrm{O}_{2}$ concentration in the air, the exposure with the use of Nocolyse One Shot will be continued in the year 2017 with the frequency of 1-2 experiments per week over a period of 6 months. 
The effects of hydrogen peroxide decontamination - tests for the presence of micro-organisms on the surface of a diving suit.

\begin{tabular}{|c|c|c|c|c|c|c|}
\hline Micro-organism & $\begin{array}{l}\text { Location } \\
\text { distance from } \\
\text { Nocospray, cm }\end{array}$ & $\mathrm{H}_{2} \mathrm{O}_{2} \%$ & $\begin{array}{l}\text { Emission } \\
\text { min }\end{array}$ & $\begin{array}{l}\text { Time } \\
\min \end{array}$ & $\begin{array}{l}\text { Result } \\
\text { From } 1+\text { to } 5+, \\
\text { from } 10^{2} \text { to } 10^{5} \text { jtk } \\
\text { pathogen at the sample } \\
\text { point } \\
0-\text { no pathogen }\end{array}$ & Comments \\
\hline All from table 1 & Suit, $150 \mathrm{~cm}$ & 0 & 0 & 0 & $5+$ & Control \\
\hline BT91 Test & table, $60 \mathrm{~cm}$ & 0 & 0 & 0 & $5+$ & Control \\
\hline BT 91 Test & $\begin{array}{l}\text { Upper surface of a } \\
\text { suspended cabinet, } \\
200 \mathrm{~cm}\end{array}$ & 0 & 0 & 0 & $5+$ & Control \\
\hline BT 91 Test & Window, $300 \mathrm{~cm}$ & 0 & 0 & 0 & $5+$ & Control \\
\hline All from table 1 & Suit, $150 \mathrm{~cm}$ & 6 & 2 & 0 & $\begin{array}{l}\text { Bacteria } 0 \\
\text { B.subtilis 3+ } \\
\text { G.stearotherm. 5+ } \\
\text { fungi, yeasts, } 0\end{array}$ & $\mathrm{H}_{2} \mathrm{O}_{2}$ \\
\hline BT 91 Test & table, $60 \mathrm{~cm}$ & 6 & 2 & 0 & $5+$ & $\mathrm{H}_{2} \mathrm{O}_{2}$ \\
\hline BT 91 Test & $\begin{array}{l}\text { Upper surface of a } \\
\text { suspended cabinet, } \\
200 \mathrm{~cm}\end{array}$ & 6 & 2 & 0 & $5+$ & $\mathrm{H}_{2} \mathrm{O}_{2}$ \\
\hline BT 91 Test & Window, $300 \mathrm{~cm}$ & 6 & 2 & 0 & $5+$ & $\mathrm{H}_{2} \mathrm{O}_{2}$ \\
\hline BT 91 Test & Suit, $150 \mathrm{~cm}$, feet & 6 & 2 & 0 & $5+$ & \\
\hline All from table 1 & Suit, $150 \mathrm{~cm}$ & 12 & 12 & 20 & 0 & $\begin{array}{l}\mathrm{H}_{2} \mathrm{O}_{2} \\
\text { One shot }\end{array}$ \\
\hline BT 91 & table, $60 \mathrm{~cm}$ & 12 & 12 & 20 & 0 & $\mathrm{H}_{2} \mathrm{O}_{2}$ \\
\hline BT 91 & $\begin{array}{l}\text { Upper surface of a } \\
\text { suspended cabinet, } \\
200 \mathrm{~cm}\end{array}$ & 12 & 12 & 20 & 0 & $\mathrm{H}_{2} \mathrm{O}_{2}$ \\
\hline BT 91 & Window, $300 \mathrm{~cm}$ & 12 & 12 & 20 & 0 & $\mathrm{H}_{2} \mathrm{O}_{2}$ \\
\hline BT 91 & Suit, $150 \mathrm{~cm}$, feet & 12 & 12 & 20 & 0 & $\mathrm{H}_{2} \mathrm{O}_{2}$ \\
\hline
\end{tabular}

\section{DISCUSSION}

The conducted experiments showed a high biocidal efficiency of the hydrogen peroxide/water/air mixture emitted by the Nocospray device manufactured by Oxypharm. A particularly effective preparation was Nocolyse One Shot containing 12\% stabilised hydrogen peroxide solution. The degree of microbiological contamination of the tested surfaces following the decontamination procedure was greatly below the acceptable level in a hospital environment [9]. Manual surface decontamination (using generally available detergents combined with a chloride bleach) did not guarantee comparable biocidal properties, especially on the external surface of a diving suit. The observations were consistent with the work by Cooper et al. [10].

The use of the BT91 test as a routine biological indicator evaluating the biocidal effectiveness of hydrogen peroxide using Geobacillus stearothermophilus spores has confirmed the principle that the elimination of the presence of spore-forming bacteria from a surface guarantees liquidation of other bacteria, viruses and mould [11].

The application of a $12 \%$ hydrogen peroxide solution with the emission of 5 to $10 \mathrm{ml}$ Nocolyse One Shot per one $\mathrm{m}^{3}$ of the tested room has guaranteed full penetrability of the biocidal agent even into very narrow spaces (diameter $9 \mathrm{~mm}$, depth $45 \mathrm{~mm}$ ).

The circulation of the decontamination mixture forced through air circulation inside the suit enabled a complete decontamination of the interiors of boots and other difficult-to-access areas of protective clothing.

\section{BIBLIOGRAPHY}

1. International Scientific Forum on Home Hygiene 2011, The chain of infection transmission in the home and everyday life settings, and role of higiene in reducing the risk of infection . dostępne na stronie http://www.ifh-homehygiene.org;

2. Noble WC. Dispersal of skin microorganisms. British Journal of Dermatology 1975:93:477-85;

3. Neely AN, Maley MP. Survival of enterococci and staphylococci on hospital fabrics and plastic. Journal of Clinical Microbiology 2000;38:724-6;

4. Brady MT, Evans J, Cuartas J. Survival and disinfection of parainfluenza viruses on environmental surfaces. American Journal of Infection Control 1990;146:47-51;

5. Neely AN,Orloff MM. Survival of some medically important fungi on hospital fabrics and plastics. Journal of Clinical Microbiology 2001;39:33601 ;

6. Sattar SA, Springthorpe S, Mani S, Gallant N, Nair RC, Scott E, Kain J. Transfer of bacteria from fabrics to hands: development and application of quantitative method using Staphylococccus aureus as model. Journal of Applied Microbiology 2001;90:962-70;

7. Grare M, Dailloux M, Simon L, Dimajo P, Laurain C. Efficay od Dry Mist of Hydrogen Peroxide (DMHP) against Mycobacterium tuberculosis and use of DMHP for Routine Decontamination of Biosafety Level 3 Laboratories. Journal of Clinical Microbiology 2008:2955-2958;

8. Barbut F, Manuet D, Verachten M, Girou E. Comparison of the Efficacy of a Hydrogen peroxide Dry-Mist Disinfection System and Sodium Hypochlorite Solution for Eradication Clostridium difficile Spores. Infection Control and Hospital Epidemiology 2009;30:507-514; 
9. Dancer SJ, How do we assess hospital cleaning? A proposal for microbiological standards for surface hygiene in hospital. J.Hosp Infect 2004:56: 10-15;

10. Cooper RA, Griffith CJ, Malik RF, Obee P,Looker N. Monitoring the effectiveness of cleaning in four British hospitals. J Hosp Infect 2007;35: 338-341

11. Heckert RA, Best M, Jordan LT, Dulac GC, Eddington DL, Sterritt WG. Efficacy of Vaporized Hydrogen Peroxide against Exotic Animal Viruses. App. Envirin.Microbiol.1997; 63:3916-3918

dr n. biol. Zbigniew Dabrowiecki

Zakład Medycyny Morskiej i Hiperbarycznej

Wojskowy Instytut Medyczny

ul. Grudzińskiego 4 81-103 Gdynia 3 skr. poczt. 18

$$
\text { tel: } 604291581
$$

e-mail: zdabrowiecki@wim.mil.pl 